\title{
BLACK SINGERS AND PLAYERS
}

\section{By NATALIE CURTIS-BURLIN}

W HO trains the chorus? It is marvelous!" The question was eagerly put by a young German musician who was visiting the Hampton Institute in Virginia and for the first time heard the great chorus of nine hundred colored students sing the "Plantations," as the Negroes call the old melodies that had their birth in days of slavery,-religious songs that were the voice of the bondsman's soul. From a technical as well as purely musical standpoint, the extraordinary unity, the precision in "attack" and the faultless pitch of the Negro singers impelled the musician's query.

And my answer baffled him: "Why, no one trains these Negro boys and girls, their singing is natural."

"I don't mean," he persisted, "who trains their voices (of course, I understand that these are natural voices), but who teaches them their parts, soprano, alto, tenor, bass,-who drills them as a chorus?"

"No one."

He stared at me incredulously. But I assured him that these black singers made up the "parts" themselves extemporaneously and sang together with the same spontaneity of unity that individuals feel when, gathering with a group, they fall in line and keep step as they walk. This quick contagion of musical sympathy, this instant amalgamation of the personal musical consciousness into a strong mass-feeling, - this it is that would make "chorusdrilling" certain death to the inspirational spirit of those superbly simple old Negro songs.

But the musician would not believe that such results could be achieved by instinct alone. And so I finally referred him to Major Moton, now Booker Washington's successor as principal at Tuskeegee, who was at that time commandant at Hampton and sang the solo parto-the "Lead" (leader), in Negro musical parlance.

His reply emphasized through its laughing surprise the inborn, intuitive quality of the Negro's love for music.

"Why, nobody ever taught us to sing!"

"Well then, how do you do it?" asked the musician in amazement. 
"I don't know. We just sing-that's all!"

Surely a people who can "just sing" in extemporaneous four and six and eight part harmonies are gifted not only with rare melodic and rhythmic sense, but also with a natural talent for harmony that distinguishes the black race as among the most musically endowed of peoples.

These nine hundred boys and girls at Hampton whose chorus singing is so "marvelous" are not divided and seated according to "parts" like the usual white chorus: indeed, technically speaking, this is no "chorus" at all,-only a group of -students at the Hampton Institute who sing because music is a part of their very souls. And so in chapel, where the old "plantations" are sung, the boys sit together at the sides, and the girls sit together in the middle, each singing any part that happens to lie easily within the range of his or her voice, harmonizing the slave-songs as they sing.

A first alto may be wedged between two sopranos with a second alto directly in front of her. A boy singing high tenor may have a second tenor on one side of him and a second bass on the other. But the wonderful inspirational singing of this great choir is sustained without a flaw or a single deviation in pitch through song after song, absolutely without accompaniment.

"How do they do it?" One may well ask! For the singing is not only faultless in its simple and natural beauty, but profoundly stirring in its emotional wealth of feeling. Few listeners can withhold a catch in the throat when, after the final benediction in chapel, a deep silence which seems to hover like a benediction itself over those hundreds of bowed heads, is broken by a softbreathed note of music, almost inaudible at first; like hushed wings, like the descent of the Holy Spirit. And then, still breathed rather than sung, gathering in volume as group after group catches it up, from those bent black heads rises a chanted "Amen," of such penetrating sweetness, such prayerful intensity that,-well, every white person that I have ever seen visit Hampton for the first time leaves chapel wiping his eyes!

"Only in Russia," declared one musician, "have I heard chorus singing comparable to this." Indeed, in my opinion, at Hampton, Tuskeegee and Fisk Institutes, and other southern schools, are to be found the great choruses of America.

Through the Negro this country is vocal with a folk-music intimate, complete and beautiful. Not that this is our only folklore, for the song of the American Indian is a unique contribution to the music of the world; also our Anglo-Saxon progenitors brought 
with them the songs and ballads of the British Isles still held in purity in the mountain fastnesses of the Southern States, though strange versions of them crop up in the cow-boy songs of the frontier. But it is the Negro music (with its by-product of "Ragtime") that to-day most widely influences the popular song-life of America, and Negro rhythms have indeed captivated the world at large." Nor may we foretell the impress that the voice of the slave will leave upon the art of this country-a poetic justice this! For the Negro, everywhere discriminated against, segregated and shunned, mobbed and murdered,-he it is whose melodies are on all our lips, and whose rhythms impel our marching feet in a "war for democracy." The irresistible music that wells up from this sunny and unresentful people is hummed and whistled, danced to and marched to, laughed over and wept over, by high and low and rich and poor throughout the land. The down-trodden black man, whose patient religious faith has kept his heart still unembittered, is fast becoming the singing voice of all America.

And how spontaneously he sings. Who can forget the first concert given by the "Clef Club," a Negro orchestra in New York, before a large and representative white audience about eight years ago in Carnegie Hall? Music-loving Manhattan felt a thrill down its spine such as only the greatest performances can inspire when, at a climax in the opening piece (a march composed by the colored leader), that entire Negro orchestra of over a hundred men burst out singing as they played!

"Can you imagine," whispered to me in the midst of the music a guarantor of one of our great orchestras, "Can you imagine our white musicians singing while they play?"

"And do you know," I whispered back, "that the man playing a tenor solo on the 'cello may be singing first bass ("baritone" the Negroes call it), and that the big man playing the bass drum

Igome have denied that our popular American muric of to-day owes its itimulus to the Negro. A most interesting end conclurive eccount of the evolution of "Regtime" is contained in the "Autobiography of an Ex-Colored Man" by Jamea Weldon Johnson, published by Brown, Little \& Co., Barton. "Rag-time" is not unjuntly condemned by many for the vulgurity of its frat aseocintions, vulgarity thet cannot bo too deeply deplored but which is lortunetely. last slipping ont of the march and dance songe of to-day. Yet this fint weociation can not annihilate the interest of the Negro rhythmic form from which oprang "Regtime," for this form hes intrinsic character. Though now videly copied and almost mechanically manufectured by commercial white cong-writern of chenp and "catchy" music, the extreordinary epncopation of "Bag-time," which make the rhythm so compelling, is undoubtedly Negro end of real value end interest murically. Nor is thi rhythmic peculiarity confined, with the Negra, to popular end secular muric only. Lifted into noble breadth of accent, syncopation in found in the old Spiritualo, or prayer-onger, for it is the rhythm natural to the Negro; intensely raciel, its counterpart may be found in the native African conos from the Dert Continent-Se r Porword to "Nerro Palk-Songs" Book II. G. Schirmer, N. Y. and Boston, 1818. 
and cymbals may be caroling a high falsetto, while the first violin sings second bass?"

For I had been to rehearsals of the Clef Club and I knew that these men who sang simply because music burst out of them, thought no more of playing one part on their instrument and another on their larynx - all at the same timo-than their cousins in Africa think of clapping one rhythm with their hands while with their feet they dance a different one. Indeed, the men of a European orchestra, each carefully schooled to automatic accuracy in his given role, would be as baffled if called upon to do the almost inhumanly difficult things that these intuitive black players did naturally, as would be the member of a white chorus if asked to improvise alto or tenor while those around them sang different parts! The average Negro, in music, seems inspired as compared to the letter-ridden, unimaginative, uncreative, and prosaic (however correct) white performer.

Buried in New York's "Black Belt"-congested streets wholly populated by thousands of colored people who are restricted to these cramped quarters-the Clef Club had played a year or two for its colored patrons before its existence was discovered by the white directors of the Music School Settlement for Colored People, 1 who then brought it to Carnegie Hall and to the knowledge of all Manhattan. Few of the players in that great band of about a hundred and twenty-five members had at that time received any musical training whatever. They were-by profession!-elevatormen, bell-boys, porters, janitors, or followers of still humbler tasks, for few trades-unions then admitted colored men, 80 that the vocations open to the Negro were about as restricted and overcrowded as the Negro streets themselves. These men met together and played and gave concerts in the "colored quarter" simply because music was an irresistible human outlet for them, and they loved it. Each man played any instrument that he happened to know and fancy. There were many violins, violas, 'cellos and double basses; but it was a motley group of plectrum instruments of all sorts and sizes-mandolins, guitars, banjos, and a few ukeleles, that gave to the immense tone of the huge band an absolutely distinctive sound, a "tang" like the flavor of pine-apple amid other fruits. Then there was an indiscriminate assortment

\footnotetext{
1"The Muvic School Settlement for Colored People" is an institution to which penerou aid ahould be piven. It hes become a civie and cocial center in the largent Negro quarter of New York and during the war it hw offered recreation and help to colored soldiers and ailors, to Red Cross ectivities and to Negro war-workers of all kinds. It is ritunted at 0 Fent 131at Street, New York City, and in under the murical direction of the telented colored composer, W. J. Rousmond Johnson.
} 
of reed and wind instruments including several magnificently regal trombones that strode forth with a sound of crimson pomp amid the trembling sway and glitter of the mandolins; there were drums and tambourines, big and little, whose sharp accents danced across the jagged syncopations of the music, recalling the elaborate drum-orchestras of Africa; there was an inspired timpanist whose swiftly rolling sticks evoked music like the sound of in-sweeping and breaking waves; there was a huge bass drum, humorous, dramatic, sometimes even tragic; and-

"Well, Mr. Mannes," explained one of the violinists to David Mannes when we were together interviewing the band prior to its first concert for white people- "well, Mr. Mannes, at our concerts we usually have to have about ten upright pianos in five pairs, back to back, running in a half circle 'round the edge of the orchestra."

"Ten pianos!" (in amazement).

"Yes sir," (very quietly) "ten pianos."

"Get to your pianos!" the Negro conductor would call at rehersal. "Get to your pianos!" And then truly beautiful, rich and unusual was the color and body given to this band of plectrum, strings and brass by the adroit manipulations of those ten little uprights which were treated purely as orchestral instruments, weaving a sonorous background of tremolos, deepening with tone-values the roll of the kettle-drums, sharpening percussion effects with varieties of pitch, emphasizing rhythmic outline, coloring the accents, blending strings, brass, plectrum and drums into a vibrant unity of sound $-a$ link between them all.

"Barbaric," one college bred Negro called the Clef Club. "Barbaric" we exclajmed in astonished admiration. That an orchestra of such power, freshness, vitality and originality could have remained so long undiscovered in novelty-hunting $\mathrm{New}$ York, was a silent and reproachful comment on the isolation of the "Negro quarter."

And such rehearsals-pathetic in their poverty of opportunity! A crowd of colored men stuffed suffocatingly under the low ceiling of a room that had seen better days as a private dwelling before the elevated railroad made life impossible and the street was abandoned to Negroes. No acoustics, no elbow-room even, the bass tube threatening with annibilation the poor drummer next him who could hardly lift his sticks without hitting the cornetplayer. Perhaps one or two in each group could read musicthe rest simply caught by ear what their neighbors played and then joined in. 
"I always put a man that can read notes in the middle where the others can pick him up," explained the conductor. There were not enough music-stands, and so here and there the notes would be spread on a chair over which a single, sophisticated player would peer and bend, while five or aix eager heads hovered near him, mouths open, musical intuition alert in every eye, "picking him up."

"Oh yes," the conductor said, "they can catch anything if they hear it once or twice, and if it's too hard for 'em the way it's written, why, they just make up something else that'll go with it."

And this wes so- once they had caught the main outline of the music, the whole band began to improvise. And how quick they were! It was mostly dance music that they played-typical Negro syncopated dance and march-rhythm. To my astonished question: "But how can they play a new piece in public next week when they've never even tried it over yet?" The leader replied:

"Don't you worry! Once those fellows hear that music and catch its swing they'll eat it right up!" They did. And then New York ate them. That first concert of Negro music in Carnegie Hall was an ear-opener. The dance craze was then sweeping the city, and the Negro players were feverishly demanded. The sun shone, the colored musicians became professional, the band split up into smaller groups and much hay was made. This was the lighter side. But those of us who had attended those first rehearsals and had seen the colored players in their shirt-sleeves bending over their instruments in that stifling room, weary from menial toil, yet singing their hearts out (they were there because the day's work was over, or the "boss" had let them off), we realized the unconscious spirit of creative art that stirred in that humble group and we felt, with reverence, as though we had been present at a birth. We had seen the racial soul, denied all opportunity, awake, nevertheless, and sing; and the song, ephemeral though it was, seemed a prophecy of the dignity and worth of Negro genius. 